\title{
TINDAK PIDANA KORUPSI DAN SANKSI PIDANA MATI PERSPEKTIF KEADILAN HUKUM
}

\author{
Amirullah \\ Institut Agama Islam Negeri Sunan Ampel, Jl. A Yani I 17 Surabaya | \\ amirpramaha50@gmail.com
}

\begin{abstract}
Corruption is included as a crime which expands into a transnational crime, destroying the moral values of the nation, hampering and harming the development of the nation, a creation of a closed path of justice, prosperity and welfare of the Indonesian people. Death penalty is an option of criminal sanctions applied in the legal system in Indonesia. The death penalty attached and integrated in the legal system in Indonesia which was formerly influenced by the complexity of its background. At the philosophical level it shows that all legislations related to the formulation of corruption and death penalty have the background of moral values based on Pancasila as a philosophical footing. The death penalty of corruption in Indonesia within the perspective of a legal justice, contained in the formulation of Law No. 20 year 2001 about the Amendment of Law No. 31 year 1999 about eradication to corruption, chapter II, article 2, paragraph (2), shows a part of the positive law. The image of the positive law in Indonesia recognizes the existence of natural law. It is reflected in the philosophical values of the nation, Pancasila (believe in one God). Consequently, the products of the positive law in Indonesia must be derived from the natural law, and the natural law is derived from the eternal law (divine law).
\end{abstract}

Keywords: Law, corruption, criminal act, justice.

Abstrak: Korupsi termasuk kejahatan yang bersifat meluas menjadi kejahatan transnasional, menghancurkan nilai-moral bangsa, menghambat dan merugikan pembangunan bangsa serta menutup jalan terciptanya keadilan, kemakmuran dan kesejahteraan bangsa Indonesia. Sanksi pidana mati merupakan pilihan pemberian sanksi pidana yang diterapkan dalam sistem hukum di Indonesia. Sanksi pidana mati melekat dan menyatu dalam sistem hukum di Indonesia yang dipengaruhi oleh kompleksitas latar belakang. Pada tingkat filosofis 
menujukkan bahwa semua rumusan perundang-undangan terkait tindak pidana korupsi dan hukuman mati memiliki latar nilai moral berdasarkan Pancasila sebagai pijakan filosofisnya. Sanksi pidana mati tindak pidana korupsi di Indonesia perspektif keadilan hukum, termuat dalam rumusan Undang-Undang No. 20/200I tentang Perubahan atas Undang-Undang No. 3 I/I 999 tentang Pemberantasan Tindak Pidana Korupsi, Bab II, Pasal 2, ayat (2), menunjukkan bagian dari hukum positif. Citra hukum positif di Indonesia mengakui keberadaan hukum kodrat. Tercermin dari nilai filosofis bangsa, yakni Pancasila, yang mengimani Ketuhan Yang Maha Esa. Konsekuensinya, produk hukum positif bangsa Indonesia harus merupakan turunan dari hukum kodrat, dan hukum kodrat turunan dari hukum Abadi (Ilahi).

Kata Kunci: Hukum, korupsi, tindak pidana, keadilan.

\section{Pendahuluan}

Penyikapan secara yuridis terhadap tindak pidana korupsi sebagai terjemahan dari konstitusi dapat diartikulasikan sebagai kesepakatan bersama dan sudah berdialog panjang dengan realitas budaya hukum masyarakat. Namun yang menjadi pertanyaan adalah mengapa realitas korupsi semakin mengalami perkembangan meningkat, bahkan sulit teratasi hanya dengan mengandalkan penerapan perundang-undangan.

Secara empiris, berdasarkan hasil pengamatan dua tahun terakhir tentang tindak pidana korupsi di Indonesia telah membuat masyarakat tersentak. Pertama, liputan surat kabar, majalah, tabloid, internet news, secara mengejutkan telah memberitakan kasus korupsi. Kedua, pada Tahun 2005, indeks persepsi korupsi Indonesia yang diumumkan Masyarakat Transparansi Internasional (MTI) berada pada angka 2.2, atau naik 0.2 dari tahun sebelumnya yang hanya 2.0. Indonesia berada pada posisi kelompok keenam dari bawah diantara 136 negara. ${ }^{1}$

Realitas korupsi di Indonesia menurut lembaga Survey Internasional Political and Economic Risk Consultancy (Hongkong)

Forum Pemantau Pemberantasan Korupsi, "United Nation Against Corruption (UNCAC), 2003', 2005 
merupakan negeri terkorup di Asia. Indonesia terkorup di antara 12 negara di Asia, diikuti India dan Vietnam. Thailand, malaysia, dan Cina berada pada posisi keempat. Sementara negara yang menduduki peringkat terendah tingkat korupsinya adalah Singapura, Jepang, Hongkong, Taiwan dan Korea Selatan. Pencitraan Indonesia sebagai negara paling korup berada pada nilai 9,25 derajat, sementara India 8,9; Vietman 8,67; Singapura 0,5 dan Jepang 3,5 derajat dengan dimulai dari 0 derajat sampai $10{ }^{2}$

Hasil riset yang dilakukan oleh berbagai lembaga, juga menunjukkan bahwa tingkat korupsi di Indonesia yang mayoritas penduduknya beragama Islam ini termasuk yang paling tinggi di dunia. Bahkan koran Singapura, The Straits Times, sekali waktu pernah menjuluki Indonesia sebagai the envelope country. Mantan ketua Bappenas, Kwik Kian Gie, menyebut lebih dari Rp.300 triliun dana dari penggelapan pajak, kebocoran APBN, maupun penggelapan hasil sumberdaya alam, menguap masuk ke kantong para koruptor. Di samping itu, korupsi yang biasanya diiringi dengan kolusi, juga membuat keputusan yang diambil oleh pejabat negara menjadi tidak optimal. Heboh privatisasi sejumlah BUMN, lahirnya perundang-undangan UU Energi, juga RUU SDA, impor gula dan beras dan sebagainya dituding banyak pihak sebagai kebijakan yang sangat kolutif karena di belakangnya ada motivasi korupsi. ${ }^{3}$

Potret buram bangsa Indonesia sebagai Negara korup kembali dipertegas oleh Transparency International Indonesia (TII) yang meluncurkan hasil survey Indeks Persepsi Korupsi (IPK) tahun 2007 pada tanggal 6 Desember 2007. Dari 180 negara yang disurvei, Indonesia berada di peringkat 143 bersama Rusia, Togo, dan Gambia. Nilai IPK itu juga memasukkan Indonesia ke

\footnotetext{
${ }^{2}$ Lembaga Survey Internasional, Political and Economic Risk Consultancy, Kompas, 2004

${ }^{3}$ M Ismail Yusanto, "Islam dan Jalan Pemberantasan Korupsi," http: / b.domaindlx.com / samil / 2004 / read news. tajuk.
} 
dalam daftar negara yang dipersepsikan terkorup di dunia, bersama 71 negara berindeks di bawah $3 .^{4}$

Sementara istilah tindak pidana korupsi tidak dikenal dalam Peraturan Penguasa Perang Pusat Kepala Staf Angkatan Darat tanggal 16 April 1958 No. Prt/Peperpu/013/1958 (BN No. 40 Tahun 1958). Istilah tindak pidana korupsi dipergunakan pertama kali dalam Peraturan Pemerintah Pengganti Undang-Undang (Perpepu) No. 24 Tahun 1960 Tentang Pengusutan, Penuntutan, dan Pemeriksaan Tindak Pidana Korupsi. ${ }^{5}$ Peperpu ini dulu sering disebut Peraturan Pemberantasan Korupsi Tahun 1960, dan berfungsi sebagai perangkat hukum pidana tentang korupsi menggantikan kedudukan Peraturan Penguasa Perang Pusat Kepala Staf Angkatan Darat tanggal 16 April 1958 No. Prt/Peperpu/013/1958 (BN No. 40 Tahun 1958). ${ }^{6}$

Fakta yuridis di atas menjelaskan bahwa Peraturan Pemerintah Pengganti Undang-Undang (Perpepu) No. 24 Tahun 1960 dengan UU No. 1 Tahun 1960 ditetapkan menjadi undangundang definitif atau UU No. 24/Prp/1960. Undang-undang ini menunjukkan sebagai hukum pidana khusus tentang tindak pidana korupsi yang bersifat definitif di Indonesia, sehingga kemudian populer dengan sebutan Undang-Undang antikorupsi. Mengapa demikian? Karena sebagaimana ciri Undang-undang pidana khusus, disamping memuat hukum pidana materiil juga memuat hukum pidana formil. Namun di balik ini semua,

\footnotetext{
${ }^{4}$ IPK atau yang dalam bahasa Inggris disebut Corruption Perception Index (CPI) merupakan salah satu alat yang dibuat oleh Transparency International untuk mengukur tingkat korupsi di berbagai negara di dunia. Seperti sudah jelas diimplikasikan oleh namanya, IPK dihasilkan dari survei persepsi. Persepsi secara definisi adalah realitas yang dipercaya (perceived reality), yang dimiliki individu dari informasi yang terkumpul, kemudian diinterpretasi dengan berdasarkan pengalaman dan pengetahuannya. Indeks persepsi korupsi karenanya merupakan representasi dari pandangan responden mengenai tingkat korupsi di dalam daerah di mana dia tinggal.

${ }^{5}$ Penjelasan Umum Peraturan Pemerintah Pengganti Undang-Undang (Perpepu) No. 24 Tahun 1960 tentang perbuatan melawan hukum adalah onrechmatige daad sebagaimana yang dimaksud dan diatur dalam pasal 1365 BW; Tiap perbuatan yang melanggar hukum yang membawa kerugian kepada orang lain, mewajibkan orang yang karena salahnya menrbitkan kerugian itu, mengganti kerugian tersebut. R. Subekti, 1999, 349

${ }^{6}$ Adam Chazawi, Hukum Pidana Materil dan Formil Korupsi di Indonesia, 2005, 3.
} 
menunjukkan bahwa realitas korupsi di Indonesia sudah menjalar, terutama pada tingkat pejabat atau pegawai pemerintahan.

Oleh karena itu, secara umum predikat korupsi di Indonesia telah diletakkan sebagai perilaku yang membudaya, bahkan merasuki seluruh sendi-sendi kehidupan bangsa. Namun demikian, ada pihak lain yang menyatakan bahwa korupsi belum membudaya, walaupun harus diakui korupsi telah sangat meluas. Laporan Bank Dunia, ${ }^{7}$ mengungkapkan bahwa Indonesia memiliki reputasi yang buruk dari segi korupsi dan menjadi salah satu negara terkorup di dunia. Dari laporan Bank Dunia itu pula menemukan bahwa korupsi di Indonesia memiliki akar panjang ke belakang yaitu sejak jaman VOC sebelum tahun 1800, dan praktek itu berlanjut sampai masa-masa pasca kemerdekaan. ${ }^{8}$

Dari masa inilah Indonesia mewarisi praktek-praktek seperti membayar untuk mendapatkan kedudukan di pemerintahan, mengharapkan pegawai-pegawai, menutup biaya di luar gaji dari gaji mereka dan lain-lain. Selanjutnya masa Orde Baru yaitu selama 1967-1998, praktek korupsi ini mendapat dukungan dan kesempatan luas, yaitu dengan memberikan dukungan kepada pengusaha-pengusaha besar dan membangun konglomeratkonglomerat baru. Di samping memberikan kemudahankemudahan dan fasilitas, bahkan memberikan kesempatan kepada para pengusaha dan kroni kekuasaan untuk mempengaruhi politisi dan birokrat. ${ }^{9}$

Berdasarkan hal di atas, maka dapat dipahami mengapa sebagai masyarakat mengharapkan agar pelaku tindak pidana korupsi dijatuhi hukuman mati. Hukuman mati bukan hanya bersifat pemberian sanksi hukuman dalam keadaan khusus sebagaimana dalam peraturan terkini. Karena perkembangan tindak pidana korupsi di Indonesia berjalan searah dengan

\footnotetext{
${ }^{7}$ The World Bank, Memerangi Korupsi di Indonesia, 2003, 3.

${ }^{8}$ Ibid,. 50.

9 Hamdanzoelv, Fenomena Korupsi Di Indonesia Dari Sudut Pandang Filsafat IImu, diupadate tanggal I I August 2008. http://hamdanzoeva.wordpress.com
} 
kemajuan bangsa. Korupsi telah diposisikan sebagai kejahatan yang mengakar di tubuh bangsa Indonesia. Kondisi ini memaksa bukan hanya pada upaya pemberantasan tindak pidana korupsi melalui pengaturan kategori tindak pidana khusus, melainkan sampai pada tingkat upaya pemberian sanksi maksimal, berupa hukuman mati. Walaupun pencantuman hukuman mati dalam tidak pidana korupsi bersifat khusus.

Namun di sisi lain, pemberian sanksi hukum mengalami perkembangan yang meletakkan pergeseran, khususnya pemberian sanksi hukuman mati. Hukuman mati diposisikan sebagai bentuk hukuman yang melanggar hak dasar kemanusiaan untuk hidup. ${ }^{10}$ Di samping itu, efek jera yang dilahirkan oleh hukuman mati tidak menunjukkkan bukti signifikan dan berlaku efektif dibandingkan hukuman lainnya. ${ }^{11}$

Sementara kehadiran sanksi pidana mati tidak bisa dilepaskan dari Kitab Undang-undang Hukum Pidana (KUHP) Indonesia yang berasal dari Wetboek van Strafrecht (WvS), yang tidak lain merupakan Kitab Undang-undang Hukum Pidana Belanda, dan mulai diberlakukan sejak 1 Januari 1918 berdasarkan asas konkordansi. Selanjutnya dinasionalisasikan dengan Undangundang No. 1 Tahun 1946. Oleh karena itu, peletakan hukum mati ini dalam perundangan-undangan sebagaimana tercantum dalam Wetboek van Strafrecht (WvS) dapat dipahami sebagai factor social.12 Karena pemerintah Indonesia ternyata juga

\footnotetext{
10 Pasal 28A UUD '45 (Amandemen Kedua) berbunyi: setiap orang berhak untuk hidup serta berhak mempertahankan hidup dan kehidupannya. Sementara itu pasal 28I ayat (I) UUD '45 (Amandemen Kedua) berbunyi: hak untuk hidup, hak untuk tidak disiksa, hak kemerdekaan pikiran dan hati nurani, hak beragama, hak untuk tidak diperbudak, hak untuk diakui sebagai pribadi di hadapan umum, dan hak untuk tidak dituntut atas dasar hukum yang berlaku surut adalah hak asasi manusia yang tidak dapat dikurangi dalam keadaan apapun.

" Survey yang dilakukan PBB pada 1998 dan 2002 tentang hubungan antara praktek hukuman mati dan angka kejahatan pembunuhan menunjukkan, praktek hukuman mati lebih buruk daripada penjara seumur hidup dalam memberikan efek jera pada pidana pembunuhan. Tingkat kriminalitas berhubungan erat dengan masalah kesejahteraan atau kemiskinan suatu masyarakat dan dan berfungsi atau tidaknya institusi penegakan hukum. Diakses tanggal 10 Agustus 2006, http://id.wikipedia.org/w/index.php? hukuman_mati

${ }^{12}$ J.E. Sahetapy, Ancaman Pidana Mati Terhadap Pembunuhan Berencana, 1979, 29
}

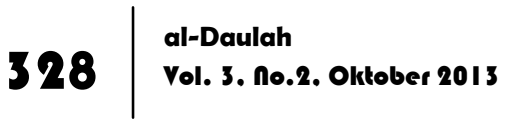


mengeluarkan undang-undang, selain KUHP, yang mengandung ancaman hukuman mati. ${ }^{13}$

Hal ini menunjukan bahwa ancaman hukuman mati yang terdapat di dalam Kitab Undang-undang Hukum Pidana Belanda, juga turut di berlakukan dalam Kitab Undang-undang Hukum Pidana Indonesia dan masih tetap diberlakukan sampai sekarang. Padahal Belanda sendiri pada 1970 telah menghapus hukuman mati untuk kejahatan biasa, dan selanjutnya pada 1982 Belanda menghapus hukuman mati untuk semua jenis kejahatan. ${ }^{14}$

Indonesia termasuk salah satu negara yang masih menerapkan ancaman hukuman mati dalam sistem hukum pidananya. Baik dalam Kitab Undang-undang Hukum Pidana maupun di luar Kitab Undang-undang Hukum Pidana terdapat beberapa pasal yang berisi ancaman hukuman mati.

Demikian pula dalam Rancangan Kitab Undang-undang Hukum Pidana masih terdapat ancaman hukuman mati. Beberapa pasal yang mencantumkan hukuman mati dalam Rancangan Kitab Undang-undang Hukum Pidana.

Begitu juga dalam Rancangan Kitab Undang-undang Hukum Pidana, hukuman mati sebagai bentuk pidana pokok yang bersifat khusus dan selalu diancamkan secara alternatif. Selanjutnya disebutkan bahwa pidana mati secara alternatif dijatuhkan sebagai upaya terakhir untuk mengayomi masyarakat.

Realitas korupsi dan sanksi pidana mati sebenarnya dua realitas yang terpisah, tetapi dikaitkan, khususnya dalam pelaksanaan hukum pidana di Indonesia. Korupsi sebagai kejahatan (tindak pidana) akan berhubungan dengan sanksi pidana mati, ketika memiliki prasyarat keadaan tertentu sesuai dengan perundangan-undangan yang berlaku saat ini. Namun demikian, korupsi dan sanksi pidana mati sebagai fenomena

${ }^{13}$ Andi Hamzah dan A. Sumangelepu, Pidana Mati di Indonesia, Di Masa Lalu, Kini dan Di Masa Depan, 1985, 17-18.

${ }^{14}$ Adri Noor Rachman, Hukuman Mati di Indonesia, di akses tanggal 10 Agustus 2008, http:// abolishment.blogspot.com 
hukum menyatu sebagai bagian dari hukum. Penyatuan inilah yang melahirkan perdebatan terkait dengan perwujudan keadilan hukum di Indonesia.

Semuanya ini menunjukkan bahwa tindak pidana korupsi dan hukuman mati sebagai sanksi pidana alternatif merupakan realitas yang disatukan pada tingkat yuridis. Pergeseran sanksi pidana mati dari pidana pokok menjadi pidana pokok alternatif juga melahirkan pertanyaan baru pada tingkat akar sosiologi hukum, minimal telah melahirkan pro dan kotra. Di samping itu, juga melahirkan pertanyaan baru dalam kerangka filofosis yang berujung pada gugatan keadilan hukum. Walaupun demikian, sisi lain argumentasi penerimaan terhadap korupsi dengan sanksi pidana mati juga melibatkan aspek yuridis, sosiologis dan filosofis.

Oleh karena itu, eksistensi korupsi dan sanksi pidana membutuhkan kajian lebih mendalam terkait dengan rumusan Undang-Undang No. 20/2001 tentang Perubahan Atas UndangUndang No. 31/1999 tentang Pemberantasan Tindak Pidana Korupsi, Bab II, Pasal 2;

(1) Setiap orang yang secara melawan hukum melakukan perbuatan memperkaya diri sendiri atau orang lain atau suatu korporasi yang dapat merugikan keuangan negara atau perekonomian negara, dipidana penjara dengan penjara seumur hidup atau pidana penjara paling singkat 4 (empat) tahun dan paling lama 20 (dua puluh) tahun dan denda paling sedikit $R p$. 200.000.000,00 (dua ratus juta rupiah) dan paling banyak $R p$. 1.000.000.000,00 (satu milyar rupiah).

(2) Dalam hal tindak pidana korupsi sebagaimana dimaksud dalam ayat (1) dilakukan dalam keadaan tertentu, pidana mati dapat dijatuhkan.

Sementara penjelasan keadaan tertentu ditegaskan pada Pasal 2, ayat (2);

Yang dimaksud dengan keadaan tertentu dalam ketentuan ini adalah keadaan yang dapat dijadikan alasanpemberantasn pidana bagi pelaku tindak pidana korupsi yaitu apabila tindak pidana tersebut 
dilakukan terhadap dana-dana yang diperuntukkan bagi penanggulangan keadaan bahaya, bencana alam nasional, penanggulangan akibat kerusuhan social yang meluas, penanggulangan krisis ekonomi dan moneter, dan penanggulangan tindak pidanan korupsi. ${ }^{15}$

Dalam rumusan di atas, jelas dapat dipahami bahwa; 1) ada kenyataan korupsi sebagai tindakan manusia, 2) ada tindakan korupsi manusia yang diposisikan sebagai perilaku melawan hukum, amoral (jahat), 3) ada tindakan korupsi sebagai tindakan yang diberi sanksi hukum, dan 4) ada tindakan korupsi yang disanksi dengan hukuman mati. Berdasarkan empat kenyataan ini, maka perlu dikaji lebih dalam terkait dengan rumusan tersebut, terutama menyangkut aspek substansi keadilan hukum.

Kajian mendalam ini bukan hanya pada tingkat rumusan normatif perundang-undangan tersebut. Lebih dari itu yaitu menyangkut kajian pada tingkat apakah sebenarnya sejatinya korupsi sebagai bentuk perilaku jahat manusia? Dan mengapa sanksi kematian menjadi salah satu pilihan untuk tindak pidana korupsi? Serta bagaimana keduanya didudukan dalam keadilan hukum manusia Indonesia? Untuk menjawab hal ini dibutuhkan telaah rumusan normatif pada Undang-Undang No. 20/2001 Tentang Perubahan Atas Undang-Undang No. 31/1999 Tentang Pemberantasan Tindak Pidana Korupsi, Bab II, Pasal 2, dengan pendekatan filsafat hukum.

Pertanyaan di atas butuh dipecahkan, karena yang melakukan korupsi adalah manusia, dan yang akan dihukum dan menghukum mati adalah manusia. Sementara setiap manusia membutuhkan keadilan hukum. Oleh sebab itu, dalam penelitian ini akan mnelaah Tindak Pidana Korupsi dan Sanksi Pidana Mati di Indonesia berdasarkan keadilan Hukum.

15 Undang-Undang No. 20/200I Tentang Perubahan Atas Undang-Undang No. 31/1999 Tentang Pemberantasan Tindak Pidana Korupsi, Bab II, Pasal 2, dan Pe njelasannya, dalam Adam Chazawi, Lampiran Hukum Pidana Materiil dan Formil Korupsi di Indonesia, 2005

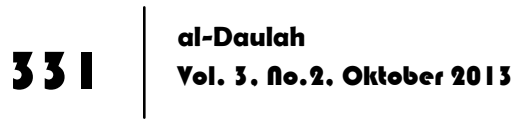


Penelitian ini memiliki tiga variable, yakni variable tindak pidana korupsi, variable sanksi pidana mati dan variable perspektif filsafat hukum. Pertalian variable pertama dan kedua terumuskan dalam Undang-Undang No. 20/2001 Tentang Perubahan Atas Undang-Undang No. 31/1999 Tentang Pemberantasan Tindak Pidana Korupsi, Bab II, Pasal 2.

Dari rumusan perundang-perundang tersebut, maka akan dikaji lebih mendalam terkait dengan eksistensi perilaku korupsi, sanksi pidana mati pada tingkat normative dan filsafat hukum $^{16}$ Sehingga semua terkait dengan hakikat, nilai dan tujuan korupsi sebagai perilaku kejahatan manusia, sanksi pidana mati dan keadilan hukum. Berdasarkan hal ini, maka dalam penelitian ini akan dilakukan dengan kajian pendekatan perundang-perundangan dan pendekatan filsafat hukum.

\section{Pemaknaan Korupsi}

Istilah korupsi berasal dari bahasa Latin, corruptio, corruptus. Berarti suatu perbuatan buruk, busuk, bejat, dapat disuap, tidak bermoral. Dalam Bahasa Arab dikenal dengan istilah riswah, artinya penggelapan, kerakusan, amoralitas, dan segala penyimpangan kebenaran. ${ }^{17}$ Korupsi terkadang dapat membawa dampak positif di bidang social, tetapi pada umumnya korupsi menimbulkan inefisiensi, ketidakadilan, dan ketimpangan. ${ }^{18}$

Menurut Juniadi Soewartojo, korupsi merupakan tingkah laku atau tindakan seseorang atau lebih yang melanggar normanorma dengan menggunakan dan atau menyalahgunakan kekuasaan atau kesempatan melalui proses pengadaan, penetapan pungutan penerimaan atau pemberian fasilitas atau jasa lainnya yang dilakukan pada kegiatan penerimaan dan atau pengeluaran uang atau kekayaan, penyimpangan uang atau kekayaan serta

\footnotetext{
${ }^{16}$ Sebagaimana disampaikan Gijssels dan Hoecke, dalam bukunya Jhonny Ibrahim, Teori dan Metodologi Penelitian Hukum Nornatif, (Malang, Bayumedia Publishing, 2006) 212

${ }^{17}$ Somasi, Mencabut Akar Korupsi, 2003, 2.

${ }^{18}$ Robert Klitgaard, Ronald Maclean Abaroa dan H. Lindsey Paris, Penuntun Pemberantasan Korupsi dalam Pemerintahan daerah, 200 I, hlm. 2-3
} 
dalam perizianan dan atau jasa lainnya dengan tujuan keuntungan pribadi atau golongan sehingga langsung atau tidak langsung merugikan kepentingan dan atau keuangan atau kekayaan Negara atau masyarakat. ${ }^{19}$

Kartini Kartono menjelaskan bahwa korupsi merupakan tingkah laku individu yang menggunakan wewenang dan jabatan guna mengeduk keuntungan pribadi, merugikan kepentingan umum dan Negara. Jadi korupsi merupakan gejala saah urus dari kekuasaan, demi keuntungan pribadi. Salah urus terhadap susmber-sumber kekayaan Negara dengan menggunakan wewenang dan kekuatan-kekuatan formal (misalnya dengan alasan hukum dan kekuatan senjata) untuk memperkaya diri sendiri. ${ }^{20}$

Pengertian korupsi dipahami sebagai misuse of public power for private benefit, ${ }^{21}$ dan juga dalam pengertian the use of public for private gain, baik untuk kepentingan yang bersifat financial maunpun nonfinansial. ${ }^{22}$ Dalam hal ini yang termasuk dalam kategori korupsi adalah sogokan (brivery), pemerasan (extortion), memperjualbelikan pengaruh (influence peddling), nepotisme (nepotism), dan segala tindakan yang terkait dengannya. ${ }^{23}$

Korupsi menurut As Hornby dan H. Wakefield adalah the offering and accepting of bibes (penawaran atau pemberian dan penerimaan suap). M.H. McKee memberikan definisi yang sederhana tentang korupsi sebagai penyalah gunaan kekuasaan untuk kepentingan pribadi. Orang tidak dapat menganggap korupsi selalu sama dan mempunyai dampak atau motivasi yang sama. ${ }^{24}$

19 Junaidi Soewartojo, Korupsi (Pola Kegiatan dan Penindakannya seta Peran Pengawasannya Dalam Penanggulangannya, 1998, 13.

${ }^{20}$ Kartini Kartono, Patologi Sosial, 2005, 90.

${ }^{21}$ Bryan W. Husted, Culture and international Anti Corruption Agreeements in Latin America, 2002, 413-422.

${ }^{22}$ Lal Balkaran, Curbing Corruption: The Internal Auditor, 2002, hlm. 40-47

${ }^{23}$ Syed Hussein Alatas, Sosiologi Korupsi Sebuah Penjelajahan dengan Data Kontemporer, 1981

${ }^{24}$ Uraian di atas oleh David M. Chalmers diistilahkan sebagai material corruption. Bentuk lain yang diperkenalkan Chalmers adalah political corruption dan intelectual corruption. Yang dimaksud 
David M. Chalmers mengatakan pembayaran terselubung dalam bentuk pemberian hadiah, ongkos administrasi, pelayanan yang berlebihan, pemberian hadiah kepada sanak keluarga, dorongan untuk mempengaruhi, dukungan untuk meningkatkan kedudukan sosial, atau hubungan apa saja yang merugikan kepentingan dan kesejahteraan umum, dengan atau tanpa pembayaran dianggap sebagai perbuatan korupsi. Bahkan David M. Chalmers menjelaskan: "the term is often applied also to misjudgments by officials in the public economies". ${ }^{25}$

Menurut ketentuan-ketentuan yang diatur dalam UndangUndang (UU) No. 31/199926 juncto UU No. 20/200127 tentang Pemberantasan Tindak Pidana Korupsi, maka korupsi itu adalah perbuatan:

1. Melawan hukum yang merugikan keuangan negara dan atau perekonomian negara (Pasal 2 ayat 1 ) ..... dipidana penjara 4 20 tahun dan denda Rp. 200 juta - Rp. 1 milyar; atau dapat juga dihukum mati;

2. Menyalahgunakan kewenangan karena jabatan atau kedudukan yang dapat merugikan keuangan negara atau perekonomian

dengan political corruption adalah korupsi dalam pemilihan umum. Termasuk didalamnya adalah memperoleh suara dengan uang, janji tentang jabatan, pemberian hadiah khusus (serangan fajar), paksaan, intimidasi, dan campur tangan terhadap kebebasan memilih. Pembelian suara dalam legislatif, pembelian keputusan-keputusan administratif, ataupun keputusan-keputusan politik termasuk dalam kategori political corruption. Sementara itu, yang dimaksud dengan intellectual corruption adalah apabila sesorang memberikan informasi atau menerangkan sesuatu yang berhubungan dengan ilmu pengetahuan dengan cara yang tidak sebenarnya, yang biasanya dilatarbelakangi oleh kepentingan-kepentingan tertentu seperti kepentingan politik, ekonomi, keuntungan diri, dan sebagainya. Lihat Baharuddin Lopa, "Kejahatan Korupsi dan Penegakan Hukum" 2002.

${ }^{25}$ Jeremy Pope, "Pengembangan Sistem Integritas Nasional, 1999

26 Undang-Undang Nomor 31 Tahun 1999 Tentang Pemberantasan Tindak Pidana Korupsi, disahkan, diundangkan, dan mulai berlaku pada tanggal 16 Agustus 1999 melalui Lembaran Negara Republik Indonesia Tahun 1999 Nomor 140, dan Penjelasannya dimuat di dalam Tambahan Lembaran Negara Republik Indonesia Nomor 3874.

${ }^{27}$ Undang Undang Republik Indonesia Nomor 20 Tahun 200I Tentang Perubahan Atas Undang Undang Nomor 31 Tahun 1999 Tentang Pemberantasan Tindak Pidana Korupsi, disahkan, diundangkan, dan mulai berlaku pada tanggal 21 Nopember 2001 melalui Lembaran Negara Republik Indonesia Tahun 200 I Nomor 134 dan Penjelasannya dimuat di dalam Tambahan Lembaran Negara Republik Indonesia Nomor 4 I 50. 
Negara (Pasal 3) dipidana penjara seumur hidup dan/atau atau 1 tahun denda Rp. 50 juta - Rp. 1 milyar;

3. Pemberian suap kepada Pegawai Negeri termasuk Hakim maupun Advokad (Pasal 5, 6, 11, 12 huruf a, b, c, d, dan Pasal 13) ..... dipidana penjara $1-5$ tahun dan denda Rp. 50 juta - Rp.250 juta; penjara $3-15$ tahun dan/atau denda Rp. 150 juta Rp.750 juta; penjara seumur hidup - 20 tahun dan denda Rp200 juta - Rp.1 milyar; penjara paling lama 3 tahun dan/atau denda Rp.150 juta;

4. Penggelapan dalam jabatan dan pemalsuan atau penghancuran atau penghilangan dokumen (Pasal 8, 9 dan10) ..... dipidana penjara 3 - 15 tahun dan denda Rp.150 juta - Rp.750 juta; penjara 1 - 5 tahun dan denda Rp. 50 juta - Rp. 250 juta; penjara 2 - 7 tahun dan denda Rp. 100 juta - Rp. 250 juta;

5. Pemerasan dalam jabatan (Pasal 12 huruf e, f, dan $\mathrm{g}$ ) ..... dipidana penjara seumur hidup - 20 tahun dan denda Rp. 200 juta - Rp. 1 milyar;

6. Pemborongan yang melakukan perbuatan curang (Pasal 7, 12i) .... dipidana penjara $2-7$ tahun dan denda Rp. 100 juta Rp. 350 juta; penjara seumur hidup - 20 tahun dan denda Rp. 200 juta - Rp. 1 milyar;

7. Gratifikasi yaitu pasal 12 B ..... dipidana penjara seumur hidup - 4 tahun dan denda Rp. 200 juta - Rp. 1 milyar; ${ }^{28}$

${ }^{28}$ Istilah gratifikasi masih belum populer di Indonesia. Masyarakat cenderung bisa menerima perilaku gratifikasi. Ada kebiasaan-kebiasaan yang termasuk dalam kategori gratifikasi. Namun, banyak yang tidak mengetahuinya. Menurut penjelasan Pasal I2B UU No. 20/200 I gratifikasi adalah pemberian dalam arti luas yang meliputi pemberian uang, barang, rabat (discount), komisi, pinjaman tanpa bunga, tiket perjalanan, fasilitas penginapan, perjalanan wisata, pengobatan cuma-cuma, dan fasilitas lainnya. Gratifikasi tersebut bisa diberikan di dalam negeri maupun di luar negeri, baik yang memakai sarana elektronik maupun yang tidak memakai sarana elektronik. Setiap gratifikasi kepada pegawai negeri atau penyelenggara negara dianggap pemberian "suap", apabila berhubungan dengan jabatannya dan yang berlawanan dengan kewajiban atau tugasnya. Menurut Pasal I2B UU No. 20/200I bagi penerima gratifikasi diganjar pidana seumur hidup, atau pidana paling singkat 4 tahun dan pidana denda paling sedikit Rp. 200.000.000,00 (dua ratus juta rupiah) dan paling banyak Rp. I.000.000.000,00 (Rp I Milyar). Kecuali, apabila penerima gratifikasi melaporkannya ke KPK dalam waktu 30 hari setelah diterimanya gratifikasi. Untuk kepentingan ini KPK telah menyediakan formulir-formulir yang bisa diisi. Kemudian kewajiban KPK menetapkan apakah gratifikasi tersebut berkaitan dengan jabatan 
8. Percobaan, pembantuan, atau pemufakatan jahat untuk melakukan tindak pidana korupsi (Pasal 15) ..... dipidana mati atau penjara 1 tahun dan denda Rp. 100 juta - Rp.1 milyar;

\section{Pemaknaan Pidana Mati}

Pidana mati adalah sebuah sanksi pidana dalam KUHP yang paling berat, karena pada dasarnya sanksi ini adalah urutan teratas atau paling tinggi di dalam sanksi pidana di dalam KUHP, dan sanksi ini telah menimbulkan banyak perdebatan para ahli hukum tanah air maupun perdebatan para ahli hukum Negara lain.

Sesuai hukum di Indonesia, pidana mati dijatuhkan atas 1) kasus pembunuhan berencana dan sengaja; 2) usaha membunuh Presiden atau Wakil Presiden atau yang membuat mereka tak berdaya untuk memerintah; 3) pengkhianatan; 4) pembunuhan berencana terhadap kepala negara dari negara sahabat; 5) pembajakan yang menyebabkan kematian; 6) pencurian yang mengakibatkan kematian; 7) menghasilkan, memproses, menyaring, mengubah atau menyediakan narkotika; 8) kejahatan terhadap kemanusiaan; dan 9) terorisme, dan 10) korupsi dalam pemenuhan syarat keadaan tertentu. ${ }^{29}$

dan tanggung jawabnya atau tidak. Apabila berkaitan dengan jabatan dan tanggung jawabnya, maka gratifikasi tersebut diserahkan kepada negara. Apabila hasil penelitian KPK gratifikasi tersebut tidak berkaitan dengan jabatan dan tanggung jawabnya, maka dikembalikan kepada penerima gratifikasi.

29 Khususnya, pidana mati diberikan dalam ketetapan KUHP berikut: Pasal 104 (Usaha dengan sengaja menghilangkan nyawa Presiden atau Wakil Presiden atau menghilangkan kebebasan mereka atau membuat mereka tidak cocok untuk memerintah); pasal I I I (kolusi dengan kekuatan asing yang mengakibatkan perang); pasal I23 (masuk pelayanan militer di sebuah negara yang perang dengan Indonesia); pasal 124 (membantu musuh); pasal 127 (penipuan dalam menyampaikan bahan-bahan militer pada saat perang); pasal 140 (pembunuhan berencana terhadap kepala negara dari negara sahabat); pasal 340 (pembunuhan dengan sengaja dan terencana); 365 (pencurian yang mengakibatkan kematian); dan pasal 444 (pembajakan yang mengakibatkan kematian seseorang). Undang-undang berikut juga berisi ketetapan yang memperbolehkan pidana mati sebagai hukuman maksimum: Undang-undang Darurat No. 12/195I; KUHPM (Kitab Undang-undang Hukum Pidana Militer); Undang-undang No. 5/1997 tentang Obat Psikotropik; Undang-undang No. 22/I997 tentang Narkotika; Undang-undang No. 26/2000 tentang Pengadilan HAM; dan Undang-undang No. I5/2003 tentang Pemberantasan Kejahatan Terorisme. Undang-Undang No. 20/200I Tentang 
Pada tahun 1998, Indonesia memulai program reformasi atas hak-hak politik dan kemanusiaan. ${ }^{30}$ Tahun berikutnya, Amnesty International menyambut pencabutan Undang-undang Antisubversi, sebuah undang-undang yang menghukum dan memprotes mereka. Namun secara damai kebijakan pemerintah dengan hukuman maksimum berupa hukuman mati, secara luas juga digunakan untuk memenjarakan tahanan, baik yang menyuarakan pendapatnya maupun tahanan politik, dimana beberapa dari mereka telah dipidana mati.

Indonesia telah mensahkan sejumlah pakta internasional tentang HAM, dan berkomitmen untuk mensahkan yang lainnya dalam waktu dekat. Dalam proses reformasi Indonesia harus menjamin bahwa hukum tersebut sesuai dengan standar internasional yang menyangkut pidana mati, dimana sedapat mungkin memberikan perlindungan pada setiap individu yang menghadapi pidana mati.

Amnesti International juga sangat prihatin bahwa dua undang-undang yang baru saja diadopsi, Undang-undang tentang Pengadilan HAM (Undang-undang No. 26/2000) dan Undangundang Pemberantasan Aksi Kejahatan Terorisme (Undangundang No. 15/2003), keduanya berisi ketentuan-ketentuan tentang pidana mati. Hal ini berlawanan dengan kecenderungan internasional yang ingin menghapuskan atau membatasi jumlah jenis kejahatan yang dapat dijatuhi pidana mati.

Komisi HAM PBB berkali-kali telah menyerukan kepada negara-negara di dunia untuk membatasi jumlah jenis kejahatan yang dapat dijatuhi pidana mati. Resolusi Majelis Umum PBB No. 32/61 menyatakan bahwa;

“.....tujuan utama dalam hal pidana mati yang harus diikuti adalah pembatasan secara progresif jumlah jenis

Perubahan Atas Undang-Undang No. 31/1999 Tentang Pemberantasan Tindak Pidana Korupsi, Pasal 2, ayat (2)

${ }^{30}$ Karena pemerintah Indonesia menjalankan transisi menuju demokrasi, reformasi HAM berada di antara tuntutan kunci untuk diubah, walaupun penghapusan pidana mati tidak termasuk sebagai bagian dari program reformasi itu. 
pelanggaran yang dapat dijatuhi pidana mati, dan menuju pada keinginan untuk menghapuskan jenis hukuman ini...."31

Itu sebabnya Amnesty International menghimbau pemerintah Indonesia untuk memperbaiki semua pasal-pasal yang relevan dalam KUHP (Kitab Undang-undang Hukum Pidana) yang saat ini sedang direvisi, sehingga tidak lagi terdapat ketentuan untuk pidana mati.

\section{Tindak Pidana Korupsi dan Saksi Pidana Mati dari Normatif Menuju Filosofis}

Sebenarnya realitas korupsi dan kematian merupakan realitas yang terpisah dan berbeda. Realitas ini bertemu dan menjadi bagian yang tidak terpisahkan, ketika lahir sebuah rumusan Undang-Undang No. 20/2001 Tentang Perubahan Atas UndangUndang No. 31/1999 Tentang Pemberantasan Tindak Pidana Korupsi, Bab II, Pasal 2, yang menyatakan bahwa:

(1) Setiap orang yang secara melawan hukum melakukan perbuatan memperkaya diri sendiri atau orang lain atau suatu korporasi yang dapat merugikan keuangan negara atau perekonomian negara, dipidana penjara dengan penjara seumur hidup atau pidana penjara paling singkat 4 (empat) tahun dan paling lama 20 (dua puluh) tahun dan denda paling sedikit Rp 200.000.000,00 (dua ratus juta rupiah) dan paling banyak Rp 1.000.000.000,00 (satu milyar rupiah).

(2) Dalam hal tindak pidana korupsi sebagaimana dimaksud dalam ayat (1) dilakukan dalam keadaan tertentu, pidana mati dapat dijatuhkan.

Sementara penjelasan keadaan tertentu ditegaskan pada Pasal 2, ayat (2);

Yang dimaksud dengan keadaan tertentu dalam ketentuan ini adalah keadaan yang dapat dijadikan alas an pemberantasn

\footnotetext{
${ }^{31}$ Resolusi Majelis Umum PBB No. 32/6 I tanggal 8 Desember 1977.
} 
pidana bagi pelaku tindak pidana korupsi yaitu apabila tindak pidana tersebut dilakukan terhadap dana-dana yang diperuntukkan bagi penanggulangan keadaan bahaya, bencana alam nasional, penanggulangan akibat kerusuhan social yang meluas, penanggulangan krisis ekonomi dan moneter, dan penanggulangan tindak pidanan korupsi. ${ }^{32}$

Pertemuan dua realitas yang berbeda itu tampak pada pasal 2, ayat (2) yang menjelaskan bahwa korupsi dalam keadaan tertentu dapat dijatuhi sanksi pidana hukuman mati. Jelaslah sekarang bahwa pertemuan itu merupakan pertemuan hukum yang lahir dari peraturang perundang-undangan di Indonesia. Sebagai bagian dari hukum, maka sanksi pidana mati tindak pidana korupsi dapat dikaji pada aspek filsafat hukum.

Sebagaimana dalam pembahasan sebelumnya bahwa eksistensi normatif korupsi merupakan tindakan kejahatan yang bersifat meluas menjadi kejahatan transnasional, menghancurkan nilaimoral bangsa, menghambat dan merugikan pembangunan bangsa serta menutup jalan terciptanya keadilan, kemakmuran dan kesejahteraan bangsa Indonesia.

Sementara eksistensi normatif sanksi pidana mati merupakan pilihan pemberian sanksi pidana yang diterapkan dalam system hukum di Indonesia. Sehingga corak sanksi pidana mati masih termuat dalam beberapa perundang-undangan di Indonesia. Oleh karena itu, dapat dijelaskan bahwa eksistensi sanksi pidana mati melekat dan menyatu dalam system hukum di Indonesia yang dipengaruhi oleh kompleksitas latar belakang.

Merujuk pada rumusan perundang-undangan di atas, maka sebenarnya sanksi pidana mati diberikan kepada koruptur yang memenuhi syarat keadaan tertentu. Keadaan tindak pidana korupsi yang dilakukan; 1) terhadap dana-dana yang

\footnotetext{
32 Undang-Undang No. 20/200I Tentang Perubahan Atas Undang-Undang No. 31/1999 Tentang Pemberantasan Tindak Pidana Korupsi, Bab II, Pasal 2, dan Pe njelasannya, dalam Adam Chazawi, Lampiran Hukum Pidana Materiil dan Formil Korupsi di Indonesia, (Malang: Bayumedia, 2005)
} 
diperuntukkan bagi penanggulangan keadaan bahaya, 2) bencana alam nasional, 3) penanggulangan akibat kerusuhan social yang meluas, 4) penanggulangan krisis ekonomi dan moneter, dan 5) penanggulangan tindak pidanan korupsi.

Artinya sepanjang keadaan tertentu itu tidak menjadi bagian dari tindakan korupsi, maka sanksi pidana mati tidak pernah menyentuh para pelaku tindak pidana korupsi. Pertanyaan yang muncul kepermukaan adalah apakah tindak pidana korupsi yang tidak memenuhi syarat keadaan tertentu tidak melahirkan tindakan kejahatan yang bersifat meluas menjadi kejahatan transnasional, menghancurkan nilai-moral bangsa, menghambat dan merugikan pembangunan bangsa serta menutup jalan terciptanya keadilan, kemakmuran dan kesejahteraan bangsa Indonesia.

Pertanyaan ini mengantarkan bahwa rumusan hukum positif tersebut berangkat dari nilai tertentu sebagai dasarnya, dan juga berangkat dari fakta empiris sebagai kenyataan yang dihadapi, serta cita hukum bangsa yang menjadi tujuannya. Ketiga rangkaian inilah yang akan mengantarkan pada kajian filsafat hukum tentang sanksi hukum pidana mati tindak pidana korupsi di Indonesia.

Berdasarkan hal di atas, maka mengkaji korupsi sebagai tindakan (melawan) hukum berarti meletakkan hakikat tindakan manusia yang memiliki keterkaitan dengan moralitas. Sementara pemberian sanksi pidana mati juga merupakan tindakan manusia yang didasarkan kepada hukum. Pemberian sanksi pidana mati bukanlah tindakan bebas manusia, melainkan tindakan yang memiliki ukuran sesuai dengan kesepakatan dan aturan hukum. Oleh karena itu, keduanya tunduk dan patuh terhadap sifat relatifitas kemanusiaan yang memiliki kemungkinan pergeseran, perubahan, bahkan bertindak di luar aturan hukum tersebut.

Realitas di atas, apabila dikaitkan dengan komitmen cita hukum yang diharapkan manusia Indonesia, yakni terciptanya kesejahteraan, kemakmuran dan keadilan. Muncul pertanyaan, bagaimana rumusan tersebut telah melahirkan dan memberikan 
kesejahteraan, kemakmuran dan keadilan hukum dalam pelaksanaannya. Khusus pada aspek keadilan, tentunya bukan hanya pada wilayah keadilan hukum, termasuk keadilan sosial, keadilan ekonomi, keadilan politik, dan keadilan lainya. Hal ini bukan berarti setiap manusia tidak membutuhkan kesejahteraan dan kemakmuran sebagai nilai kemutlakannya. Namun keterkaitan hukum lebih mendominasi pada sektor perwujudan keadilan. Dalam bahasa lain perwujudan keadilan merupakan prasyarat terciptanya kesejahteraan dan kemakmuran bangsa.

Namun demikian apa yang dikehendaki dalam perwujudan hukum diharapkan segala kompleksitas tujuan yang menyatu dan menjadi bagiannya. Sebagaimana dikatakan Soetandyo Wignjosoebroto bahwa tujuan hukum adalah, berupa: ketertiban, keamanan, ketentraman, kedamaian, kesejahteraan, kebenaran dan keadilan. ${ }^{33}$ Sebagaimana menyatunya manusia hukum untuk mendapatkan ketertiban, keamanan, ketentraman, kedamaian, ksejahteraan, kebenaran dan keadilan, dalam segala kompleksitas hukum.

\section{Tindak Pidana Korupsi dan Sanksi Pidana Mati dalam Perspektif Keadilan Hukum}

Berdasarkan penjelasan di atas, maka eksistensi rumusan Undang-Undang No. 20/2001 Tentang Perubahan Atas UndangUndang No. 31/1999 Tentang Pemberantasan Tindak Pidana Korupsi, Bab II, Pasal 2, ayat (2), terkait sanksi pidana mati tindak pidana korupsi keadaan tertentu. Karena itu, semuanya harus didudukan sebagai realitas hukum positif yang hidup dan menjadi bagian masyarakat Indonesia. Realitas hukum positif ini tentunya sangat terkait dengan bangunan nilai, fakta empiris, dan cita hukum bangsa Indonesia.

Pernyataan ini menjelaskan bahwa peneliti lebih meletakkan bahwa hukum menyatu dengan moral, bukan bangunan terpisah

\footnotetext{
${ }^{33}$ Soetandyo Wignjosoebroto, Hukum: Paradigma, Metode dan Dinamika Masalahnya, 2002, 18.
}

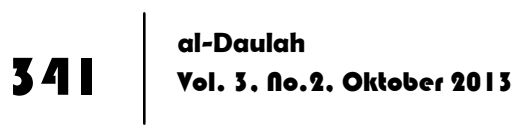


sebagaimana dikatakan Austin. Hukum positif merupakan bagian tidak terpisah dengan hukum ideal (cita hukum), sebab untuk melihat hakikat hukum positif harus kembali pada nilai, fakta empiris, dan cita hukum yang terbangun di dalamnya.

Namun demikian, dalam dunia gagasan hukum dijelaskan secara khusus dalam dialog terakhirnya Plato, Law, dan hanya dianggap riil sebagai reproduksi tidak sempurna dari gagasan mengenai hukum dan keadilan. Gagasan tentang hukum tentunya tidak bisa bertentangan dengan gagasan tentang keadilan, dan karena itu konflik aktual yang ada antara hukum dan keadilan harus ditafsirkan sebagai konsekuensi dari interpretasi tidak sempurna terhadap masing-masing gagasan. ${ }^{34}$

Dengan demikian, dapat dinyatakan bahwa hukum positif merupakan sebuah fenomena, yang tampak timbul dan tenggelam, yang berpartisipasi secara parsial dalam dunia gagasan yang tidak lekang oleh waktu, sebuah konsepsi yang berbeda jauh dari konsepsi hukum alam dalam idealism modern, dimana cita-cita keadilan sebagai norma yang lebih sempurna dihadapkan dengan hukum positif. Menurut Plato, hukum layaknya hal lain di dunia ini, pada akhirna hanyalah jembatan imajener bagi orang bijak dalam pencarian mereka atas kebenaran dan nilai-nilai. ${ }^{35}$

Dalam filsafat hukum Aristoteles yang memiliki banyak keterkaitan dengan filsafat hukum Plato, menegaskan bahwa inspirasi aseli tentang cara mengatasi situasi tertentu, pembahasannya dalam kantor dan parlemen, dan realisasi akhirnya dalam sebuah konstitusi yang masuk akal dan adil, yakni sesuai dengan situasi yang dihadapinya. Sederhanyanya semua fase penciptaan hukum harus dipahami berdasarkan tujuan akhirnya. Sementara hukum hanya bisa ditetapkan dalam kaitannya dengan keadilan. ${ }^{36}$

\footnotetext{
${ }^{34}$ Carl Joachim Friedrich, Filsafat Hukum Perspektif Historis, 2008, 20.

35 Ibid., 21.

${ }^{36}$ Carl Joachim Friedrich, Filsafat Hukum Perspektif Historis, 24.
} 
Selanjutnya mengikuti penalaran filsafat hukum Thomas Aquinas, menyatakan bahwa keterkaitan hukum positif pada hukum kodrat adalah esensial dan merupakan syarat legitimasi keberlakukan hukum positif. Hukum positif menerapkan prinsip umum hukum kodrat pada ruang lingkup khusus, sehingga secara khusus pula mempengaruhi perilaku subyek hukum positif, baik dengan cara menarik kesimpulan dari prinsip umum maupun dengan cara membentuk aturan-aturan tertentu yang diilhami oleh prinsip umum tersebut. Oleh karenanya, sesuatu diturunkan dari asas-asas umum hukum kondrat melalui proses penyimpulan, seperti misaln ya "orang tidak boleh membunuh" mungkin diturunkan dari asas "tidak seorangpun boleh berbuat jahat terhadap sesamanya". Beberapa yang lain diturunkan dengan cara ditetapkan, seperti ada hukum alam yang menyatakan bahwa semua pelaku kejahatan harus dihukum. Pada tatanan ini hukum kodarat akan menuntut subyek hukum berperilaku secara berbeda-beda, disesuiakan dengan masing-masing system hukum positifnya. Pengkhususan atas hak-hak yang berada di bawah hukum kodrat itu bergantung kepada hukum positif atau dengan kata lain hukum positif merupakan sarana atau medium untuk menerapkan asas-asas umum hukum kodrat pada penataan kehidupan nyata manusia di dalam masyarakat. ${ }^{37}$

Thomas menentukan posisi hukum kodrat dalam struktur hierarkis hukum sebagai berikut:

1. Puncak dari hierarkis adalah hukum abadi, yaitu pengaturan rasional atas segala sesuatu dimana Tuhan menjadi penguasa alam semesta.

2. Di bawah hukum abadi adalah hukum kodrat, tidak lain adalah partisipasi makhluk rasional di dalam hukum abadi. Dalam perwujudannya, hukum kodrat memiliki dua bentuk; pertama, kebijaksanaan atau kearifan yang perlu untuk menjalani hidup dengan yang oleh Aquinas disebut akal praktis; kedua, aequitas 
(equity, epieikeia), yaitu kewenangan pemerintah untuk meninggalkan ketentuan hukum jika penerapan harfiahnya justru menghilangkan "semangat kalimatnya"

3. Di bawah hukum kodrat adalah hukum positif atau hukum buatan manusia. ${ }^{38}$

Thomas menyinggung konsep tentang keadilan pada saat membahas hubungan antara hukum kodrat dengan hukum positif dan pemberlakukan didalam praktek penyelenggaraan negara. Asas-asas formal hukum kodrat menjadi rambu keadilan dalam pembuatan hukum dan kebijakan politik. Thomas mengklaim bahwa hukum positif yang adil memiliki daya ikat melalui hati nurani subyek hukum. Hukum positif akan disebut adil jika memenuhi persyatan sebagai berikut:

1. Diperintahkan atau diundangkan demi kebaikan umum

2. Ditetapkan oleh legislator yang tidak menyalahgunakan kewenangan legislatifnya

3. Hukum positif memberikan beban yang setimpal demi kepentingan kebaikan umum.

Asas-asas keadilan hukum kodrat tersebut berfungsi sebagai standart regulatif bagi hukum positif. Dengan asas tersebut kita memiliki dasar untuk mengeavalausi dan keputusan yudicial. ${ }^{39}$

Berdasarkan penalaran filosofis di atas, maka peneliti akan menganilisis realitas sanksi hukum pidana mati tindak pidana korupsi di Indonesia berdasarkan tingkat kekhususan sebagai ciri hukum positif. Rumusan Undang-Undang No. 20/2001 Tentang Perubahan Atas Undang-Undang No. 31/1999 Tentang Pemberantasan Tindak Pidana Korupsi, Bab II, Pasal 2, ayat (2), terkait sanksi pidana mati tindak pidana korupsi keadaan tertentu, pada aspek landasan nilai, sanksi hukum dan keadilan hukum.

${ }^{38}$ Carl Joachim Friedrich, Filsafat Hukum Perspektif Historis, 18.

${ }^{39}$ Carl Joachim Friedrich, Filsafat Hukum Perspektif Historis, 20. 


\section{Aspek Nilai-Moral dan Sanksi Hukum}

Mengikuti nalar Tohams Aquinas, dalam kontek keindonesiaan, maka realitas produk hukum apapun tidak bisa dilepaskan dari pengakuan terhadap Ketuhanan Yang Maha Esa. Ini menjadi pembuka untuk menjelaskan bahwa eksistensi hukum positif tersebut lahir atas keberadaan hukum abadi. Sebab pengakuan terhadap Tuhan juga mengakui hukum Abadi (Ilahi) Di samping itu, Pancasila dapat dijadikan sebagai alat evaluasi terhadap segala produk Undang-Undang, sebagaimana hukum kodrat bisa mengevaluasi hukum positif.

Rumusan Undang-Undang No. 20/2001 Tentang Perubahan Atas Undang-Undang No. 31/1999 Tentang Pemberantasan Tindak Pidana Korupsi, Bab II, Pasal 2, ayat (2) lahir dengan landasan nilai Pancasila. Dasar-dasar filosofis yang dimaksudkan lima prinsip dasar Pancasila itu mencakup sila atau prinsip (1) Ketuhanan Yang Maha Esa; (2) Kemanusiaan yang Adil dan Beradab; (3) Persatuan Indonesia; (4) Kerakyatan yang Dipimpin oleh Hikmat Kebijaksanaan dalam Permusyawaratan/ Perwakilan; dan (5) Keadilan Sosial bagi Seluruh Rakyat Indonesia. Kelima sila tersebut dipakai sebagai dasar filosofis-ideologis untuk mewujudkan empat tujuan atau cita-cita ideal bernegara, yaitu: (1) melindungi segenap bangsa Indonesia dan seluruh tumpah darah Indonesia; (2) meningkatkan kesejahteraan umum; (3) mencerdaskan kehidupan bangsa; dan (4) ikut melaksanakan ketertiban dunia berdasarkan kemerdekaan, perdamaian yang abadi, dan keadilan sosial.

Berdasarkan dasar pertimbangan lahirnya Undang-Undang No. 20/2001 Tentang Perubahan Atas Undang-Undang No. 31/1999 Tentang Pemberantasan Tindak Pidana Korupsi, yang menjelaskan bahwa tindak pidana korupsi bertentangan nilai filosofis bangsa untuk mewujudkan masyarakat adil dan makmur serta sejahtera berdasarkan Pancasila dan Undang-Undang Dasar 1945.

Berarti hakikat rumusan tersebut merupakan perwujudan nilai-nilai Pancasila. Tindak pidana korupsi dengan sanksi pidana 
mati dalam keadaan tertentu merupakan moralitas Pancasila tercermin dalam perundang-undangan. Kejahatan korupsi dengan sanksi pidana mati bukanlah realitas hukum pada umumnya, melainkan realitas hukum khusus. Sehingga pelanggaran terhadap kekhususan tersebut akan berakibat terhadap kerugian keungan dan ekonomi Negara yang lebih vital dan lebih besar.

Kalau sanksi pidana mati diterjemahkan sebagai bagian yang melanggar hak asasi manusia sebagai tertuang dalam UUD 1945 (amandemen), maka sebagai Rumusan Undang-Undang No. 20/2001 Tentang Perubahan Atas Undang-Undang No. 31/1999 Tentang Pemberantasan Tindak Pidana Korupsi, Bab II, Pasal 2, ayat (2), sebagai bagian hukum positif tidaklah menjadi persoalan. Sepanjang tidak bertentangan dengan hukum kodrat Pancasila dan pembukaan UUD 1945.

Sebaliknya korupsi haru diletakkan sebagai tindakan yang tidak mengimani Ketuhanan Yang Maha Esa, bertentangan dengan Kemanusiaan yang Adil dan Beradab; (3) melahirkan perpecahan Persatuan Indonesia; (4) menanggalkan Kerakyatan yang Dipimpin oleh Hikmat Kebijaksanaan dalam Permusyawaratan/Perwakilan; dan (5) menutup jalan terciptanya Keadilan Sosial bagi Seluruh Rakyat Indonesia. Karena hukum kodrat Pancasila yang dilanggar oleh tindakan korupsi dengan ditambah syarat kondisi tertentu yang dipenuhinya, maka menghilangkan hak dasarnya merupakan pilihan sanksi hukum yang akan mengembalikan pelestarian hukum kodrat Pancasila.

\section{Aspek Sanksi Hukum dan Keadilan Hukum}

Hukum positif realitasnya sangat terikat tempat dan waktu dimana dilahirkannya. Rumusan Undang-Undang No. 20/2001 Tentang Perubahan Atas Undang-Undang No. 31/1999 Tentang Pemberantasan Tindak Pidana Korupsi, Bab II, Pasal 2, ayat (2), merupakan gambaran terhadap dua realitas yang saling memberatkan sebagai bentuk perbuatan melawan hukum.

Dua fakta hukum tersebut, antara lain: 
a. Fakta hukum tindak pidana korupsi sebagai tindak pidana tertentu dan khusus, sehingga korupsi merupakan kejahatan khusus ditengah kejahatan pada umumnya.

b. Fakta hukum tindak pidana korupsi memiliki kondisi tertentu yang sangat membahayakan kondisi bangsa. Hal ini bukan berarti korupsi pada umumnya tidak membayakan Negara, melainkan tingkat kondisi tertentu merupakan pertemuan kondisi khusus yang menyebabkan tindakan korupsi sangat khusus di tengah ke khususannya. Akibatnya sanksi pidana mati menjadi pilihan hukum positif sebagai turunan dari hukum kodrat Pancasilan.

Berdasar hal di atas menunjukkan bahwa manusia karena kodrat rasionalnya memiliki kebebasan untuk mengambil dan menentukan sikap sendiri dalam melakukan tindakan. Dalam pembahasan filsafat hukum, kebebasan manusia memiliki banyak arti. Kebebasan manusia memainkan peranan yang sangat penting dalam pembahasan yuridis dan politis, serta dalam pembahasan tentang batsan hukum. Menurut Aquinas, hukum tidak bertentangan dengan kebebasan dan cinta, sebab cinta merupakan kecenderungan kodrat menuju kebaikan.

Kebebasan merupakan dasar dari realisasi diri manusia sebagai ciptaan yang memiliki tujuan akhir serta memiliki kecenderungan untuk berkembangan sesuai dengan tujuan tersebut. Sebagai makhluk rasional, manusia memiliki kehendak dan diharapkan dapat menguji priogatifnya ini melalui kehendaknya. Meskipun hal ini, hanya dapat terjadi jika ia berbuat dibawah kebebasan kehendaknya. Jika Thomas mendefinisikan hukum sebagai perintah akal budi dan kebebasan berakar didalam akal budi juga, maka dengan definisi ini ia hendak menegaskan bahwa kebebasan penentuan diri atas kodrat rasionalnya tidak lain adalah kebebasan memilih atau kehendak bebas. Kebebasan ini dimanifestasikan dalam hal istimewa atau hak priogratif sebagai makhluk rasional. 
Perintah akal budi merupakan sumber ketaatan moral sebagai konsekuensinya, jika hukum positif menuntut ketaatan secara moral, kekuatan tuntutan tersebut harus diturunkan dari hukum kodrat. Hal ini kiranya juga menjadi alasan mengapa hukum positif harus mendasarkan diri pada hukum kodrat. Dengan kata lain jika manusia secara moral mempunyai kewajiban untuk taat kepada hukum karena perintah hukum kodrat, maka semua ketaatan pada dasarnya berasal dari hukum kodrat.

Konsep tentangan ketaatan menuntut kita pada gasasan tentang sanksi, sebab tidak semua orang mau mentaati hukum. Semua jenis hukum, baik hukum kodrat maupun hukum positif, jika dilanggar dapat menjatuhkan sanksi. Hukum Kodrat memiliki sanksi kodrati dan sanksi ini terjadi sesuai dengan hakikat tindakan yang dilakukan manusia. Hukum positif memiliki sanksi positif, yaitu berupa sanksi fisik dan sanksi ini didasarkan atas kehendak legislator serta tidak berhubungan secara kodrati dengan tindakan yang dilakukan.

Keberlakukan hukum kodrat menghasilkan keseimbangan antara perbuatan dan kodrat kita, serta keseimbangan hubungan antara kodrat kita sebagai ciptaan, kodrat sosial dan hak kepemilikan. Melalui hukum kodrat atau di bawah naungan hukum kodrat, keberlakukan hukum dapat menjamin dan mempertahankan nilai-nilai martabat manusia. Di luar konsep hukum kodrat penerapan sanksi identik dengan penghancuran kehendak bebas. ${ }^{40}$

Berdasarkan hal ini, maka korupsi sebagai kejahatan khusus ditengah kekhususan merupakan kehendak bebas tanpa akal budi. Oleh karena itu, sanksi dapat menerjemahkan sebagai bentuk melahirkan ketaatan hukum dengan jalan menghancurkan kehendak bebasnya, yakni dengan sanksi pidana mati.

Mengapa demikian karena korupsi sudah memasuki sebagai kejahatan kleptokrasi adalah istilah yang dipergunakan untuk

\footnotetext{
${ }^{40}$ Carl Joachim Friedrich, Filsafat Hukum Perspektif Historis, 24.
} 
menunjukkan amat seriusnya tingkat korupsi suatu negara. Green (2004) merujuk rumusan Weber tentang kleptokrasi, yaitu memperoleh keuntungan melalui korupsi sebagai tujuan organisasi, kepentingan negara dan kepentingan penguasa menjadi kabur batasnya, yang merupakan pintu bagi dilakukan korupsi, termasuk penganiayaan, teror oleh negara, kejahatan perang, dan genosida.

Kata lain yang dipergunakan sebagai padanan dari kleptokrasi adalah korupsi tingkat tinggi (heavy corruption). Istilah kleptokrasi ini merupakan peningkatan dari istilah kleptomani yang berarti kebiasaan mencuri dari seseorang yang tidak dilakukan untuk pencaharian. Ia semacam gangguan psikologis yang relatif menetap. Pelakunya adalah orang-orang yang tidak mengalami kesulitan ekonomi, bahkan tidak jarang adalah orang yang dikenal publik, seperti pejabat.

Ketika tingkat korupsi di Indonesia dirasakan sangat serius, dan terjadi hampir di semua sektor kehidupan, khususnya yang berhubungan dengan birokrasi, maka dapat dikatakan bahwa kleptokrasi merupakan ciri korupsi di Indonesia. Dengan ciri kleptokrasi, maka tindakan korupsi menjadi membudaya atau dipandang lumrah saja oleh sebagian orang. Oleh karena itu tindakan korupsi menjadi tidak mudah untuk ditanggulangi.

Ciri-ciri dari suatu negara kleptokrasi antara lain adalah:

a. Tingkat korupsi yang dilakukan oleh birokrasi sangat tinggi. Birokrasi di sini tidak hanya birokrasi pemerintahan (eksekutif), tetapi juga meliputi birokrasi legislatif dan yudikatif. Sebagaimana kasus-kasus korupsi yang telah terungkap dan diajukan ke pengadilan, korupsi di kalangan birokrasi Indonesia dilakukan oleh antara lain bupati, gubernur, menteri (eksekutif), anggota-anggota DPRD dan DPR (legislatif), serta hakim dan jaksa dalam berbagai tingkat (yudikatif).

b. Ciri berikutnya adalah bahwa kaum birokrat dalam melakukan tindakan korupsi mengadakan persekongkolan 
dengan para pengusaha atau korporat. Persekongkolan birokrat dan korporat tersebut terutama dalam rangka memperoleh keuntungan keuangan dengan cara-cara yang merugikan negara. Negara kleptokrasi pada umumnya mengandalkan pembiayaan negara pada sumber daya alam yang dieksploitasi secara tidak terkendali, lebih memakmurkan birokrat yang korup dan korporasi mitranya daripada kemakmuran rakyatnya.

\section{Penutup}

Berdasarkan penjelasan tersebut, maka eksistensi sanksi pidana mati tindak pidana korupsi di Indonesia, berarti:

1. Secara normatif, tindak pidana korupsi di Indonesia sebagai kategori tindakan tertentu dan tindak pidana khusus, karena korupsi termasuk kejahatan yang bersifat meluas menjadi kejahatan transnasional, menghancurkan nilai-moral bangsa, menghambat dan merugikan pembangunan bangsa serta menutup jalan terciptanya keadilan, kemakmuran dan kesejahteraan bangsa Indonesia. Sanksi pidana mati merupakan pilihan pemberian sanksi pidana yang diterapkan dalam sistem hukum di Indonesia. Corak sanksi pidana mati masih termuat dalam beberapa perundang-undangan di Indonesia. Sanksi pidana mati melekat dan menyatu dalam sistem hukum di Indonesia yang dipengaruhi oleh kompleksitas latar belakang. Dan pada tingkat filosofis menujukkan bahwa semua rumusan perundang-undanganan terkait tindak pidana korupsi dan hukuman mati memiliki latar nilai moral berdasarkan Pancasila sebagai pijakan filosofisnya.

2. Sanksi pidana mati tindak pidana korupsi di Indonesia perspektif keadilan hukum, termuat dalam rumusan UndangUndang No. 20/2001 tentang Perubahan Atas Undang-Undang No. 31/1999 tentang Pemberantasan Tindak Pidana Korupsi, Bab II, Pasal 2, ayat (2), menunjukkan bagian dari hukum positif. Citra hukum positif di Indonesia mengakui keberadaan 
hukum kodrat. Tercermin dari nilai filosofis bangsa, yakni Pancasila, yang mengimani Ketuhan Yang Maha Esa. Konsekuensinya produk hukum positif bangsa Indonesia harus merupakan turunan dari hukum kodrat, dan hukum kodrat turunan dari hukum Abadi (Ilahi). Oleh karena itu, kejahatan korupsi sebagaimana rumusan termaktub merupakan kejahatan kleptokrasi yang melanggar hukum kodrat Pancasila, sehingga sanksinya adalah penghancuran tindakan bebas sebagai pilihan keadilannya, yakni dengan sanksi pidan mati. Sanksi pidana mati tidak tepat didialekkan dengan UUD 1945 (amandemen), sebab sanksi pidana mati dalam tindak pidana korupsi harus didialogkan dengan hukum kodrat Pancasila dalam menguji keadilan hukumnya, bukan pada tataran keadilan tindakannya.

\section{Daftar Pustaka}

Alatas, Syed Hussein. Sosiologi Korupsi Sebuah Penjelajahan dengan Data Kontemporer. Jakarta: LP3ES, 1981.

Andrews, William G. Constitutions and Constitutionalism. $3^{\text {rd }}$ edition, New Jersey: Van Nostrand Company, 1968.

Asshiddiqie, Jimly. Konstitusi \& Konstitusionalisme Indonesia. Edisi Revisi, Jakarta: Konstitusi Press, 2005.

Atmasasmita, Romli. Sistem Peradilan Pidana, Prespektif Eksistensialisme dan Abolisionisme. Bandung: Binacipta, 1996.

Chazawi, Adam. Hukum Pidana Materiil dan Formil Korupsi di Indonesia. Malang: Bayumedia, 2005.

-------. Lampiran Hukum Pidana Materiil dan Formil Korupsi di Indonesia. Malang: Bayumedia, 2005.

Freeman, M.D.A. Lloyd's Introduction to Juricprudence. Seventh Edition, London: Sweet \& Maxweel Ltd, 2001.

Ghazali (al-). Peringatan Bagi Penguasa, Agar Kekusaan Tidak Menjadi Korup. terj. M. Yudhi R. Haryono. Jakarta: Hikmah, 2001. 
Hamzah, Andi dan A. Sumangelepu. Pidana Mati di Indonesia, Di Masa Lalu, Kini dan Di Masa Depan. Jakarta: Ghlmia Indonesia, 1985.

Hartani, Evi. Tindak Pidana Korupsi. Jakarta: Sinar Grafika, 2005.

Ibrahim, Jhonny. Teori dan Metodologi Penelitian Hukum Nornatif. Malang: Bayumedia Publishing, 2006.

Kartono, Kartini. Patologi Sosial. Jilid I, Jakarta: PT. Raja Grafindo Persada, 2005.

Klitgaard, Robert dan Ronald Maclean Abaroa dan H. Lindsey

Paris. Penuntun Pemberantasan Korupsi dalam Pemerintahan

Daerah. Jakarta: Yayasan Obor Indonesia, 2001.

Lopa, Baharuddin. Kejahatan Korupsi dan Penegakan Hukum. Jakarta: Kompas, 2002.

Mahfud MD, Moh. Setahun Bersama Gus Dur Kenangan Menjadi Menteri di Saat Sulit. Jakarta: LP3ES, 2003.

Morris, Allison dan Warren Young. Reforming Criminal Justice, The Potential of Restorative Justice, dalam Restorative Justice Philosophy to Practice. edited by Heather Strang and John Braithwaite. The Australian National University: Asghate Publising Ltd, 2000.

Mukti, Krishnanda Wijaya. "Membangun Sinergi Pendidikan dan Agama dalam Gerakan Anti Korupsi", dalam buku Membangun Gerakan Antikorupsi Dalam Perspektif Pendidikan, Yogyakarta, LP3 UMY, 2004. Partnership, Governance Reform in Indonesia, Koalisi Antarumat Beragama untuk Antikorupsi.

Muladi. Kapita Selekta Hukum Pidana. Semarang: Badan Penerbit Universitas Diponegoro, 1995.

------. Lembaga Pidana Bersyarat. Bandung: Penerbit Alumni, 2002.

Munajat, Makhrus. Dekonstruksi Hukum Pidana Islam. Yogyakarta: Logung Pustaka, 2004.

Ndraha, Taliziduhu. Kybernologi Ilmu Pemerintahan Baru. Jakarta: PT Rineka Cipta, 2003. 
Ness, Daniel W. Van. Restorative justice and International Human Rights, Restorative Justice, International Perspektive. edited by Burt Galaway and Joe Hudson, Amsterdam, The Netherland: Kugler Publications, 1991.

Packer, Herbert L. The Limits of the Criminal Sanction. California: Stanford University Press, 1968.

Poernomo, Bambang. Asas-asas Hukum Pidana. Jakarta: Ghalia Indonesia, 1985.

Pope, Jeremy. Pengembangan Sistem Integritas Nasional. Buku

Panduan Transparency International, Jakarta: PT Pustaka Utama Grafiti, 1999.

Reid, Sue Titus. Criminal Justice, Procedur and Issues. New York: West Publising Company, 1987.

Sahetapy, J.E. Ancaman Pidana Mati Terhadap Pembunuhan Berencana. Bandung: Alumni, 1979.

Shomali, M.A. Relativisme Etika. ter. Zaimul Am. Jakarta: Serambi, 2005.

Soejono. Kejahatan dan Penegakan Hukum Di Indonesia. Jakarta: PT. Rineka Cipta, 1996.

Soewartojo, Junaidi. Korupsi Pola Kegiatan dan Penindakannya seta

Peran Pengawasannya Dalam Penanggulangannya. Jakarta: Balai Pusataka, 1998.

Solehuddin. Sistem Sanksi dalam Hukum Pidana, Ide Dasar Double Track System dan Implementasinya. Jakarta: Raja Grafindo Persada, 2003.

Thompson, Brian. Textbook on Constitutional and Administrative Law. edisi ke-3, London: Blackstone Press ltd, 1997.

Tonry, Micahel. Sentencing Matters. New York: Oxford University Press, 1996.

\section{Lembaga}

Forum Pemantau Pemberantasan Korupsi. United Nation Against Corruption UNCAC., 2003. Jakarta: Perum Percetakan Negara RI, 2005. 
Somasi. Mencabut Akar Korupsi. Mataram: SOMASI, 2003.

The World Bank. Memerangi Korupsi di Indonesia. Jakarta: Kantor Bank Dunia, 2003.

\section{Jurnal}

Balkaran, Lal. Curbing Corruption, The Internal Auditor. AltamontenSpring Feb., Vo 59 1, 2002.

Husted, Bryan W. Culture and international Anti Corruption Agreeements in Latin America. Journal of Business Ethics, 2002.

Tilaar, H.A.R. Pemberantasan Korupsi Melalui Pendidikan. Jurnal Dinamika Masyarakat Jakarta: Ristek, 2004.

Wignjosoebroto, Soetandyo. Korupsi Sebagai Masalah Sosial-Budaya. Jurnal Dinamika Masyarakat Jakarta: Ristek, 2004.

Winarta, Frans H. Pemberantasan Korupsi Perlu Penegak Hukum Yang Bersih. Jurnal Dinamika Masyarakat Jakarta: Ristek, 2004.

\section{Makalah}

Asshiddiqie, Jimly. Konstitusi Kesultanan-Kesultanan Islam di Jawa Barat dan Banten. UIN Gunung Djati, Bandung: 5 April 2008.

Rasul, Sjahruddin. Pembekalan Bagi Calon Duta Besar R.I. Jakarta: 3 Agustus 2005.

\section{Koran}

Asyarie, Musa. Budaya Korupsi dan Dekonstruksi Sosial. Kompas, 28 Januari 2005.

Lembaga Survey Internasional. Political and Economic Risk Consultancy. Kompas, 4 Maret 2004.

Zamjani, Irsyad. Abad Korupsi. Kompas, 8 November 2005.

\section{Internet}

Fanani, Ahmad Fuad. Dekonstruksi Budaya Korupsi. www.suaramerdeka.com, di update 18 Agustus 2005. 
Hamdanzoelv. Fenomena Korupsi Di Indonesia Dari Sudut Pandang Filsafat Ilmu. diupadate tanggal 11 August 2008. http,//hamdanzoeva.wordpress.com

Rachman, Adri Noor. Hukuman Mati di Indonesia. diakses tanggal 10 Agustus 2008, http,// abolishment.blogspot.com

Yusanto, M Ismail. Islam dan Jalan Pemberantasan Korupsi. diupdate tanggal 10 Agustus 2008, http, / b.domaindlx.com / samil / 2004 / read news. tajuk.

\section{Perundang-undangan}

Undang-Undang Dasar 1945 amandemen.

Kitab Undang Hukum Pidana

Undang-undang Darurat No. 12/1951; KUHPM Kitab Undangundang Hukum Pidana Militer..

Undang-undang No. 15/2003 Tentang Pemberantasan Kejahatan Terorisme.

Undang-Undang No. 20/2001 Tentang Perubahan Atas UndangUndang No. 31/1999 Tentang Pemberantasan Tindak Pidana Korupsi

Undang-undang No. 22/1997 tentang Narkotika

Undang-undang No. 26/2000 tentang Pengadilan HAM

Undang-undang No. 5/1997 tentang Obat Psikotropik.

Peraturan Pemerintah Pengganti Undang-Undang Perpepu. No. 24 Tahun 1960

Peraturan Penguasa Perang Pusat Kepala Staf Angkatan Darat tanggal 16 April 1958 No. Prt/Peperpu/013/1958 BN No. 40 Tahun 1958..

PP Nomor 71 Tahun 2000 Tentang Tata Cara Pelaksanaan Peran

Serta Masyarakat dan Pemberian Penghargaan Dalam

Pencegahan Dan Pemberantasan Tindak Pidana Korupsi

Resolusi Majelis Umum PBB No. 32/61 tanggal 8 Desember 1977. 